\title{
Research on the Construction of Micro Course and Teaching Innovation in Applied University
}

\author{
Erni Zhang \\ Zhengzhou University of Industrial Technology, Business College, Zhengzhou, Henan Province, \\ China, 451100
}

670031348@qq.com

Keywords: Micro course; Teaching innovation; Micro - teaching construction; Style construction; Applied university

\begin{abstract}
Applied university focuses on cultivating students' skills and individuality, which prompts the teacher's teaching methods and students to learn the way to miniaturization, mobile, fragmentation. The teaching construction of micro course relates to the validity of students' learning, while the teaching innovation determines how far the micro course can go. The purpose of this paper is to strengthen the practice of using micro-design and application aspects of exploration and teaching innovation, so as to give play to the advantages of applied universities. The methods of application are the design of micro - teaching construction, the design of micro - teaching method, the design of micro course platform, and the construction of study style. The result is the innovative teaching principle and the innovation of the teaching mode. The conclusion is that the micro course can save the time of knowledge transmission, classroom time, and can play with the role of classroom practice, which requires the construction of micro-classroom teaching, teaching innovation, to meet the application of university-running ideas.
\end{abstract}

\section{Introduction}

The 21st century is the era of knowledge economy characterized by "informatization". Education for all, education of high quality, individualized learning and life-long learning has become the important features of information age education development. School education is one of the main places, where has the formation of the correct values, the transfer of scientific knowledge, professional skills training. There are many ways to gain knowledge, the type of learning resources, teaching methods, student learning, interaction between teachers and students. There has been dramatic change[1]. With the advent of technicalization, informatization and mobility, micro course with the network, Micro course's unique advantages becomes the new direction for many colleges and universities in information technology teaching. It is a new subject of education reform, and it is also a good way to improve the quality of teaching and cultivate students' ability of independent study and innovation. It is necessary to understand the connotation and function of micro-lesson correctly, improve the ability of teachers to design and develop micro-course and to apply micro-teaching. Important means, it is the development of the contemporary era of innovation requirements, has important theoretical and practical significance[2].Micro course is to point to in a short period of time complete the content of a topic, video recording as the carrier of the teaching part of the teacher. The significance of micro course is to improve students' learning interest and learning ability through intuitive and clear learning environment. Because students' attention and energy can be highly concentrated in a short time, the time of micro course is short and the contents are less conducive to students' learning. Micro course with the network, students can learn at any time, thereby enhancing the mobility of learning.

\section{The Overview of Micro Course}

Only by correctly understanding the nature of micro course, can we do a good job in micro construction and teaching innovation, better guide practice, cultivate application - oriented talents. Micro course "micro", not small meaning, micro course and the traditional teaching as classroom 
building, teaching mode, teaching philosophy. "Micro-lesson" refers to the teaching according to the new curriculum standards and teaching practice requirements, teaching video as the main carrier, reflecting the teachers in the classroom teaching process for knowledge point or teaching links to carry out teaching and learning activities, organic combination of various teaching resources. The core content of the micro-lesson is the classroom teaching video (lesson fragment). It also includes the teaching design, material courseware, teaching reflection, practice test, student feedback and teacher's comment. Certain structural relationship and presentation together create a semi-structured, prominent theme of the resource unit application "ecological environment." Therefore, the "micro-lesson" is different from the traditional single teaching class, teaching courseware, teaching design, teaching reflection and other resource types, but also on the basis of inheritance and development of new teaching resource [3].Therefore, it can be analyzed from the following aspects:

First, Learning micro. Learning "micro" not only embodies the composition of miniature learning content chunks of knowledge content is small, but also contains knowledge is decomposed, independent of the loose knowledge, that is, we often say that fragmentation. On the one hand, "mini" learning refers to students' understanding of knowledge, learning, cognitive strategy of micro; the other hand, compared with the traditional 45-minute classroom teaching, students learning ideas, learning process is miniaturized.

Second, Content micro. The use of micro - teaching means is to improve the efficiency of teaching for the purpose. Therefore, the selection and design of the content of micro-teaching is the main factor that determines the success of micro-course. The micro-course is the key to the success of the micro-course, and the micro-teaching is not the only way to achieve the micro-teaching. The subject of micro course is generally only taught a knowledge point, through which students can grasp the focus and difficulty of the whole content; demonstration micro course demonstrates the key action skills, problem-based micro course guides students to solve the typical problems[4]. Discussion-based micro course is often focused on the theme of discussion.

Third, Time micro. The short time is the main feature of micro course, according to the theoretical point of view of teaching construction micro course length to meet the learning characteristics of students and cognitive laws. Teaching time of micro course has generally 15 minutes, in this time range of students' attention can be highly concentrated[5].

\section{The Construction of Micro Course}

The Design of Micro - teaching Construction. First, the focus of micro-teaching materials to be "small and fine", you can select part of teaching knowledge points, this knowledge points to have the independence, integrity, demonstration, representation, can effectively solve the teaching and learning process .Because of the characteristics of micro course short and pithy, the span of knowledge of micro course is inevitable, so the micro course is very important, the teaching design should be innovative, should be in short period of time to seize the students' attention; So the convergence is particularly important, the corresponding parts can be used between the pictures and video to help students accept; Finally, test the effectiveness of student learning and mastery.

The Design of Micro - teaching Method. Man as the main body of all things, plays a vital role. The teaching design of micro course including the goal of teaching, the analysis of the basic characteristics of the students, the choice of topics, the choice of teaching media tools and teaching strategies, and so on affects the teaching effect[6].

Therefore, we should pay attention to the teaching of micro-teaching teachers in the design of training, so that teachers master the design of micro course steps and related considerations to ensure that teachers know how to design. The use of tools is to distinguish the main features of people and animals, the appropriate micro-production tools, can achieve a multiplier effect; and improper teaching tools for micro-teaching quality cannot be effectively improved, and restrained and hindered the production of micro-teachers class teaching application of ideas and enthusiasm. To mobilize the enthusiasm of teachers in teaching micro-teaching, we can give teachers the full application of micro-teaching environment, at the same time to carry out in-school micro-assessment to promote evaluation, to increase the power of teachers to apply micro course. 
Design of Micro Course Platform. Micro course to the network as the support, if not for resource integration, then the significance of the students is supporting information; If you make good use of the network, the combination of various resources, the micro-platform platform, students can more easily use micro-lesson resources[7].

Micro-platform design should include the following elements: (1) the establishment of the corresponding database, make full use of network edge, seamless connection. Students use mobile phones, computers and other mobile devices log micro-platform, you can get the entire professional micro-class resources. At the same time can also be interested in their own micro-class resources, and fully mobilize the enthusiasm of students to learn and cultivate application-oriented talents. (2) Learning to learn, teach something to teach, a good evaluation of interaction is essential, the only way for teachers to obtain timely feedback, update the contents of micro-lessons, and students get feedback on their own interest in micro-class content, and then have the interest to continue learning,the two are mutually reinforcing relationship between each other. (3) the compatibility of micro-platform is better, should have the appropriate technical support, to support different mobile terminal devices.

Strengthen the Study Style Construction. Micro course to the students and teachers to bring great convenience, but also test the school's style of study. Most students self-discipline is not strong, self-control is not strong, who easy to follow the crowd, micro-class resources have been, the network platform built, but students do not want to learn, which is also a problem. Good style of study to supervise and guide students to learn, while the poor style of learning is waste of resources in micro-class, but also easily lead to students lazy style. Therefore, we should actively carry out examination reform, teaching reform, pay attention to practice, to strengthen the construction of style of study, style of study to improve student interest and increase their pressure for students to self-learning, lifelong learning.

\section{Teaching Innovation of Micro Course}

The Innovation Principle of Micro-teaching. First of all, meet the basic characteristics of application-oriented education and training needs, that is, the future employment of students oriented, training applied, practical-oriented talent. To students as the center, around the students clear teaching content and teaching objectives, and then we develop appropriate teaching tasks. At the same time, in order to meet the needs of society and enterprises, micro curriculum education should be forward-looking to the future development of enterprises need talent as the core, combined with post practice, design and enterprise job requirements similar to the teaching content, strengthen micro- Attribute, through micro-teaching innovation so that teaching and practical positions between the more fit[8].

Second, meet the principle of cognitive needs of students. The teaching construction of micro course in the application - oriented university education should conform to the students 'cognitive needs and cognitive rules. According to the students' learning interest and learning needs, the effective curriculum construction should be carried out. To design students can improve the interest of micro-teaching content, to avoid the traditional, boring, single theory of instructional design, strengthen the practice, scenarios and video teaching model to improve students' enthusiasm and enthusiasm to follow the gradual deepening principle, From simple to difficult, from shallow to deep to the knowledge points to explain, students learn self-confidence, and then enable students to master the appropriate knowledge.

Finally, avoid rigidities. There is no definite method of teaching and learning without practice. Micro course is also a way of teaching method diversity, micro course as teaching resource, applied to classroom teaching, teachers can according to their understanding of the curriculum and design, conscious use of this teaching resources, specifically when to use, how to use, depends entirely on the teacher's overall design of the course and the overall grasp.

Micro course is just teaching resource. Any kind of teaching resources, can not be required everywhere. Teachers in the classroom teaching, according to the actual situation, flexible combination of a variety of teaching resources in order to arouse students interest in learning to 
achieve better teaching results[9].

And some one-sided thought that "a separate micro-class useless, micro-lessons into a series", "micro-teaching can solve all the problems in teaching," "all the teaching content should be made of micro-class". These ideas are too rigid, In line with reality. Therefore, the micro-teaching innovation to avoid rigid, individualized, in dependence on technology, but also give full play to the subjective initiative.

Innovation of Teaching Mode. Micro course has changed the teaching structure of the classroom, Most of the traditional teaching teachers say, students listen, and the micro-design to teaching activities, students involve in teaching activities; micro course changes the students learning, allowing students according to their own progress selection and watch micro-class, and can stop, playback, fast forward, to ensure that they can understand the content, to achieve self-learning[10]. In the course of realizing the informationized teaching mode, the micro course should be combined with work and study. Pay attention to the combination of micro-education and practice, both inside and outside the school combined to strengthen micro-teaching practice and application of teaching and learning to promote the use of their own, to promote learning, learn with each other[11].Application-oriented micro-education is more integration of theoretical teaching and practical training to form a "integrated" micro-class, no longer distinguish between the traditional "theory class" and "practical course" in order to cultivate applied talents .

\section{Conclusion}

The characteristics of applied universities are to train high-quality applied talents with strong social adaptability and competitive ability. Micro course can save the time of knowledge transmission, classroom time, and can play with the role of classroom practice, which requires the construction of micro-classroom teaching, teaching innovation, to meet the application of university-running ideas.

\section{References}

[1] T.S. Hu, M.Y. Huang and M.Li: The Three Stages of the Development of Mini - lesson in China and Its Enlightenment [J].Journal of Distance Education, (2013) No.8, p.3 6. (In Chinese)

[2] Y.C. Zhang: Challenging Traditional Teaching, Leading Teaching Innovation - On Connotation, Construction and Application of Micro Curriculum [J].Jiangsu Education, (2015) No.10, p. 9. (In Chinese)

[3] T.S. Hu: "Micro - lesson": the New Trend of Regional Education Information Resources Development [J]. E-Education Research, (2011) No.10, p.13. (In Chinese)

[4] X.Y. Ren: Research on Micro - teaching[J].Journal of Beijing Xuanwu Hongqi Spare-time University, (2014) No.1, p.8. (In Chinese)

[5] J.J. Huang and S.Q. Guo: On the Design of Micro - curriculum [J].Modern Educational Technology,(2012) No.6, p.31. (In Chinese)

[6] W.H. Liu: Micro - teaching design (Higher Education Press, China 2015). (In Chinese)

[7] X.L. Liu: Higher Vocational Colleges Should Pay Attention to the Cultivation of Students' Professional [J]. Education Exploration, (2010) No.10, p.137. (In Chinese)

[8] T.S. Hu and X.Q. Zhou: Research on the Current Situation and Development Strategy of Micro - curriculum Construction in Colleges [J]. Modern Educational Technology,(2014) No.2, p.5. (In Chinese)

[9] B.Y. Li and W.Z. Lv: Theory and Skill of Micro - course (China Light Industry Press , China 2015). (In Chinese) 
[10] G.H. Liu: The Application of Microcurriculum in College Classroom Teaching [J].China Adult Education,(2014) No.6, p.122. (In Chinese)

[11] Y.C. Zhang: Research and Reflection on the Construction of Micro Course [J]. China Education Network, (2013) No.10, p.28. (In Chinese) 